\title{
Students' perspectives on buying private tuition services
}

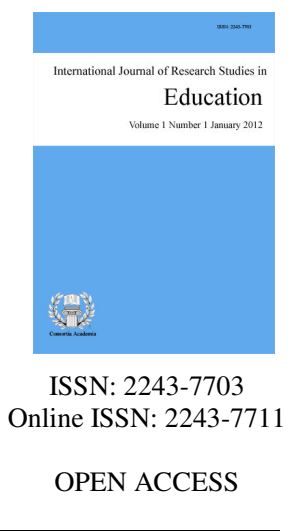

\section{Abstract}

This study aims to gather and analyze students' perspectives on buying private tutoring services, also known as shadow education (Bray, 2007). Private tutoring service has been rapidly spreading and trending around the world. Its rapid development is one of the signs of marketization and privatization in education and students as the 'consumers' of education services play crucial roles in boosting the trend of private tutoring through their demands. Analyzing and understanding their perspectives in buying private tutoring services are crucial in order to have a better understanding on factors 'forcing' them to buy shadow education services. Data were collected through students' focus group discussions to acquire their personal views and motives on buying private tutoring services. Findings indicate students buy private tutoring services due to their academic achievements and/or problem, their parents-related decision, and their view on the usefulness of private tutoring services. Understanding the motives on why students buy private tutoring services is useful to analyze how their demands are related to their dissatisfaction on the mainstream education. This study also reveals private tutoring services, and education privatization in general, is an unavoidable in the future. Schools and policymakers may start to study these phenomena thoroughly and produce reliable policies to improve students' experience in mainstream schooling.

Keywords: private tutoring; shadow education; students' perspectives; marketization in education 


\section{Students' perspectives on buying private tuition services}

\section{Introduction}

The expansion of what is known as private tutoring (also known as shadow education, due to its nature which follows the movement of mainstream education) has been rapidly growing and has become evident all around the world (Bray \& Lykins, 2012). Recent research shows shadow education trend has been spreading across the globe (Baker, Akiba, LeTendre, \& Wiseman, 2001; Buchmann, Condron, \& Roscigno, 2010; Lee, 2007), and has been considerably changing the face of education (Burch, 2009). Therefore it is impossible for education practitioners as well as policymakers to ignore this phenomenon (Bray, 2007).

Experts see shadow education as one of the effects of marketization and privatization in education (Ball, 2007; Bray, 2007), because shadow education is heavily determined and driven by the demands from the 'consumers' of the education: the students. Therefore, analyzing this trend from the perspectives of those who 'create' these demands will be a good basis to get the big picture of their motives on spending their money and sacrificing their time for this service, their expectations from buying these services, and how their demands shape the shadow education market.

As the trend of shadow education is spreading throughout the world, its rapid-growing phenomenon is also apparent in Indonesia. For instance, one of the oldest tutoring franchises in Indonesia, Primagama, has 587 outlets spread on 33 provinces ${ }^{1}$. Another franchise, Ganesha Operation, has 788 outlets in 272 cities $^{2}$. Furthermore, countless personal advertisement offering various tutoring services through mass or social media can be easily found. Despite these facts, it is very hard to find out the research on this topic in Indonesian context. Therefore, this research is conducted to further study this phenomenon in Indonesian context, to examine the trend from the perspectives of Indonesian students, to close the gap in the literature of shadow education in Indonesian context, and to further enrich the literature of shadow education.

\section{Literature Review}

Private tutoring, as a product of privatization in education sector, has become 'vast enterprise' in many countries because "it employs many thousands of people, massive amounts of money, and huge amounts of time from both tutors and students" (Bray, 2007, p. 17). Research on the trend of private tutoring have been growing rapidly in recent decades (Aurini, 2006; Baker et al. 2001; Buchmann et al., 2010; Dierkes, 2008; Lee, 2007; Mori \& Baker, 2010; Southgate, 2009), although its significance has long history in some countries but escaped the attention of researchers as well as education planners and policymakers (Bray, 2007; Foondun, 1998; Seth, 2002; Stevenson \& Baker, 1992). Asia is where private tutoring grows significantly and has been extensively researched, especially in eastern Asia where countries like South Korea, Japan, China, Hong Kong and southern Asia countries like Sri Lanka, India, Pakistan, and Bangladesh have long history of private tutoring (Bray \& Lykins, 2012; Das \& Das, 2013; Kim \& Park, 2010; Zhang \& Bray, 2013). Research on the other parts of Asia like countries in central and Southeast Asia also show prodigious growth of private tutoring (Silova, 2009; Silova, Budiene, \& Bray, 2006; Tan, 2009; Toh, 2008). The growth of this service is also detected in Europe, such as in southern Europe like Greece and Cyprus, and Western Europe countries like France, Italy, and Portugal (Bray, 2011; Bento \& Ribeiro, 2013).

\subsection{Demands of Private Tutoring}

Research mentioned above, albeit applied different methodologies and provided different data, targeted

\footnotetext{
http://primagamasiap.com/tentang-primagama

${ }^{2}$ http://www.ganesha-operation.com/about/\#!/history
} 
different foci, and had umpteen socioeconomic and geographic factors involved as well as education policies applied in the countries, expose one similar remark: private tutoring is a phenomenon trending and spreading across the globe. In this modern market-driven era, one phenomenon exists because there are demands which extend its existence (Ball, 2007). The demand for private tutoring, from one-on-one to group tutoring, has been growing in many countries. Many factors argued by experts to portray the demand of private tutoring which fuel its expansion across the globe (Baker \& LeTendre, 2005; Bray \& Silova, 2006; Brehm \& Silova, 2014). When we discuss about the demand for tutoring, students (as the consumer of this service) play crucial role because they are the ones whose demands shape the private tutoring market. Many tutors and tutoring franchises update their services by analyzing the needs of the students (Bray, 2007). Although researchers argue there are other crucial factors affecting the demand for tutoring, such as school quality (Hamid, Sussex, \& Khan, 2009; Kim, 2004, Kim \& Park, 2010), sociocultural aspects (Dang, 2008; Hrynevych, Toropova, Pylnyk, Sereda, \& Gerasevich. 2006), and even economic factor (Dawson, 2010) has its share in affecting the growth of private tutoring. But those crucial factors do not have effect in private tutoring as direct as the influence of the students who buy of private tutoring service. Hence, taking those factors and analyzing them from the students' may give a more thorough understanding on the demand for private tutoring.

Demands from Students - Examinations, in many research and contexts, appear to be the number one reason why demand for shadow education is growing considerably (Bray, 2007, 2011; Bray \& Lykins, 2012; Hamid et al., 2009; Suraweera, 2011). Many countries create and develop schooling system and curriculum obligating their students to take numerous tests and examinations during their study years and the amounts of the tests are getting higher along their way to go up to the higher level of education (Bray, 2007; Budiene \& Zabulionis, 2006; Sharma, 1997). This sort of development exacerbates the demand for private tutoring as Baker (2012) argues examination as strong driving force why students take tutoring: to get additional help in preparing themselves to face the examinations. Reay and Wiliam (1999) argue students feel their achievement in examinations determine their success in schooling and failure in exams is intolerable. Many students admit good examination results give them chance to acquire entrance to reputable schools and universities (Bray \& Lykins, 2012) and give better prospects for enhanced earnings and standard of living in the future. These high stakes examinations success is often considered as an 'effective' way for tutors and tutoring franchises in countries where high-stakes examinations exist to 'advertise' themselves to the students and parents who feel the pressure and seek private preparation help (Lipman, 2004).

Another reason perceived by many students in countries where private tutoring services are booming is that private tutoring serves as an effective path to help them to compensate their disadvantage in learning (Bray, 2012). Silova (2012) stated left behind-students believe tutoring assist them to comprehend the subjects they are left behind in, or to expand and deepen their understanding in certain subjects or topics. Additionally, many students think tutoring as their best place to do and redo tasks and get additional help until they have adequate understanding on certain subjects or topics without being afraid of punishment (Oller \& Glasman, 2013). These arguments are closely related, to some extent, to school and teaching quality. For example, Suraweera (2011, pp. 20-21) revealed in his research on Sri Lankan students that more than half (53\%) of the respondents stated they did not get sufficient exercises during their schooling and the content from the syllabus was not fully covered. Half of the respondents also indicated that they had difficulty in understanding what was taught in school, so they decide to deepen their knowledge through tutoring service. Similar remark about dissatisfaction on school quality as the reason to take private tutoring also appears in research in Turkey (Tansel \& Bircan, 2005), Azerbaijan (Silova \& Kazimzade, 2006), and Georgia (Matiasvhili \& Kutateladze, 2006).

In contrast, other research reveals different possible reasons to argue the opinions above. In East Asia countries and Singapore, where the quality of schools are considered well-developed and show strong performance in PISA (OECD, 2010), many well-performing students still pay for tutoring services and cited maintaining or enhancing good performance in schooling as their reason (Bray, 2009; Dawson, 2010; Stevenson \& Baker, 1992; Southgate, 2009). Additionally, Bray argues, "Shadow education is much less about support to those who are in real need of learning support that they cannot find at school, and a lot more about maintaining 
Sandy, W.

competitive advantages within schools for students who are already successful and privileged" (Bray, 2011, p. 33). This competitive nature of students may come from the society itself where chance of getting well-paid jobs are bigger for them who spend more time in competitive learning situation (Bray \& Kwo, 2013; Dang, 2008; Dawson, 2010). Maintaining educational success and advantages is seen as an investment for better fortune in the future and this belief boosts the demand for private tutoring and further placing private tutoring as a necessity.

\subsection{Impact of Private Tutoring}

Private tutoring brings various types of impact. The most relevant one to measure, because it is arguably useful to help students in their schooling, is its impact on students' achievement. Many students firmly believe investing on private tutoring leads to better academic achievement in schooling, although this belief is debatable. Findings in Bray and Lykins' report (2012, pp. 32-36) showed private tutoring has mixed impact on academic achievement and shadow education may not always foster students' achievements because there are other numerous education-related variables involved and cannot be undervalued (students' level, motivation of the tutors and the tutees, the quality of tutors, class size, tutoring model, tutoring duration and timing). Yet, most families assume private tutoring have beneficial effects (Wittwer, 2014) and the belief that tutoring can help make significant change in learning achievement is still present among the students. Logically speaking, tutoring provides more opportunity for the students to learn because they have more time and task to learn. However, based on the findings on the research in Bray and Lykins (2012), this is not always translated into better school achievement.

Although private tutoring does not always bring positive impact in students' achievement, it arguably brings positive effects in other factors. Wittwer (2014) argues private tutoring can give the students additional human capital, in terms of knowledge and education advantage. Bray (2007) argues tutoring can lighten teachers' burden in classroom because the time in classroom is limited to give further help for in-need students or students who need more explanation. Private tutoring is also viewed as a good help for slow learners to keep up with their peers and help fast learners stretch their learning, and even the lessons can be designed to match the needs of these students (Safarzynska, 2013; Toh, 2008). Brehm \& Silova (2014, p. 96) argue private tutoring help the students because "it offers students adequate time to cover the national curriculum, which is otherwise difficult to complete during the school day". Tutoring may also promote students' self-esteem and self-discipline because they already pay a lot of money and they have to be very discipline to attend the tutoring and push them to maximize their outcomes as they value their parents' sacrifice in paying tutoring fee (Dierkes, 2008; Kwok, 2001).

\section{Methodology}

\subsection{Research problem}

This study aims to investigate the students' perspectives on buying private tutoring services. Specifically, this study intends to gather Students own reasons on buying private tutoring services. Identifying their perspectives on buying such services is important because their reasons drive their demands for shadow education and shape the shadow education market. Therefore, this study is intended to find out the motives behind the students' decision to allocate their time after school hours and their decision to spend their money to buy private tutoring services.

\subsection{Research design}

This study employed qualitative method and to fulfill the aim of this study, focus group discussion was chosen for data collection because the writer wanted to observe and record the interaction among the participants in discussing predetermined topic in a dynamic way, and this dynamic discussion minimizes observer's bias 
because it appears from the participants' interaction (Lodico, Spaulding, \& Voegtle, 2006). Therefore, focus group discussion is deemed suitable to gather students' perspectives. The focus group discussion were set up into three phases as follows:

Discussion phase 1 - Students are going to discuss about the lessons/subjects in school that are easy and difficult for them

Discussion phase 2 - Students will discuss about private tutoring/extra course outside school hours they take and why, related to phase 1

Discussion phase 3 - Students will discuss about the benefits and drawbacks of private tutoring they take.

\subsection{Samples and sampling strategy}

As focus group discussion was chosen for data collection process, the participants of focus group discussion must share relevant characteristics and/or interests to the discussed topic (Marczyk, DeMatteo, \& Festinger, 2005).For this study, it is important to set the criteria to specify the nature of the sample and its suitability to foster the validity of the sampling (Howitt and Cramer, 2000). The writer only chose the participants based on the predetermined characteristics and knowledge related to the investigated topic and the selection criterion of the participants is straightforward: students who buy extra tutoring service after school hours.

In this study, the participants for the discussion were chosen from the list of students from a private secondary school in Pontianak, Indonesia who share one important similarity: they have extra tutoring service after school hours. From the list, ten students (five male students and five female students) were chosen. Ten participants were chosen for focus group discussions based on Morgan's (1988) suggestion (between four to twelve people) because, "too small and intra-group dynamics exert a disproportionate effect, too large and the group becomes unwieldy and hard to manage; it fragments" (Morgan, 1988, in Cohen, Manion, \& Morrison, 2000, p. 288). The participants were first contacted to ask for their availability and willingness to take part in this study. To comply with research ethical procedures (Berg, 2001), the writer also gave their parents information about the study and asked for their permission and signed the consent form because the participants were still in secondary school level (grade 8 and 9) and permission from parents is compulsory. The participants were divided into two gender-based groups because at their current age (13 to 15 years old), the students are still reluctant to fully express their ideas to the opposite gender friends, which in the context of focus group discussion setting should be avoided, because the nature and the maximum result of focus group discussion cannot be reached.

\subsection{Data collecting and analysis process}

For data analysis, transcripts from focus group discussions were created based on audio recordings and then interpreted into English. These transcripts were later analyzed using thematic analysis method (Braun \& Clarke, 2008) to analyze and identify the emerging themes from the data (inductive) and further analyzed to see whether the themes resemble themes already exist from the literature (deductive) or there might be new set of themes around the topic discussed of this research (Boyatzis, 1998). In doing thematic analysis, the six phases of analysis from Braun and Clarke (2008) were applied to add validity of the result, as follows:

$>\quad$ Phase 1: familiarizing yourself with your data (Creating transcription)

$>\quad$ Phase 2: generating initial codes

$>\quad$ Phase 3: searching for themes

$>\quad$ Phase 4: reviewing themes

$>$ Phase 5: defining and naming themes

$>$ Phase 6: producing the report 
Sandy, W.

\section{Table 1}

Six phases of analysis

\begin{tabular}{|c|c|c|}
\hline Process & No & Criteria \\
\hline Transcription & 1 & $\begin{array}{l}\text { The data have been transcribed to an appropriate level of detail, } \\
\text { and the transcripts have been checked against the tapes for } \\
\text { 'accuracy'. }\end{array}$ \\
\hline Coding & $\begin{array}{l}4 \\
5 \\
6\end{array}$ & $\begin{array}{l}\text { Each data item has been given equal attention in the coding } \\
\text { process. } \\
\text { Themes have not been generated from a few vivid examples (an } \\
\text { anecdotal approach), but instead the coding process has been } \\
\text { thorough, inclusive and comprehensive. } \\
\text { All relevant extracts for all each theme have been collated. } \\
\text { Themes have been checked against each other and back to the } \\
\text { original data set. } \\
\text { Themes are internally coherent, consistent, and distinctive. }\end{array}$ \\
\hline Analysis & $\begin{array}{c}7 \\
\\
8 \\
9 \\
10\end{array}$ & $\begin{array}{l}\text { Data have been analyzed, interpreted, made sense of rather than } \\
\text { just paraphrased or described. } \\
\text { Analysis and data match each other the extracts illustrate the } \\
\text { analytic claims. } \\
\text { Analysis tells a convincing and well-organized story about the } \\
\text { data and topic. } \\
\text { A good balance between analytic narrative and illustrative } \\
\text { extracts is provided. }\end{array}$ \\
\hline Overall & 11 & $\begin{array}{l}\text { Enough time has been allocated to complete all phases of the } \\
\text { analysis adequately, without rushing a phase or giving it a } \\
\text { once-over-lightly. }\end{array}$ \\
\hline Writing report & $\begin{array}{l}12 \\
13 \\
14\end{array}$ & $\begin{array}{l}\text { The assumptions about, and specific approach to, thematic } \\
\text { analysis are clearly explicated. } \\
\text { There is a good fit between what you claim you do, and what } \\
\text { you show you have done - ie, described method and reported } \\
\text { analysis are consistent. } \\
\text { The language and concepts used in the report are consistent with } \\
\text { the epistemological position of the analysis. } \\
\text { The researcher is positioned as active in the research process; } \\
\text { themes do not just 'emerge'. }\end{array}$ \\
\hline
\end{tabular}

One of the phases in thematic analysis which is very crucial in generating themes is coding (Saldana, 2009). In this research, coding was conducted to filter and highlight important aspects of the transcripts to generate categories and themes. For this study, three cycles of coding were implemented: This first cycle of coding was applied to analyze keywords and phrases that were common in the transcripts. Keywords and phrases appeared were analyzed and encoded with suitable category labels. The keywords and phrases occurring in the data were then grouped and drawn in a mind-map poster to get the big picture of the codes. Next, the second cycle was used to recognize similar codes and summarize them into (sub-) categories. The codes may be used repetitively if they fit into several categories. Then, the third cycle of coding was applied to further analyze results from the first two stages and discover how the new categories and sub-categories interrelated with one another. The process of coding of the data of this research is shown in the following figures:

Figure 1. Coding (color codes were assigned to group similar keywords)

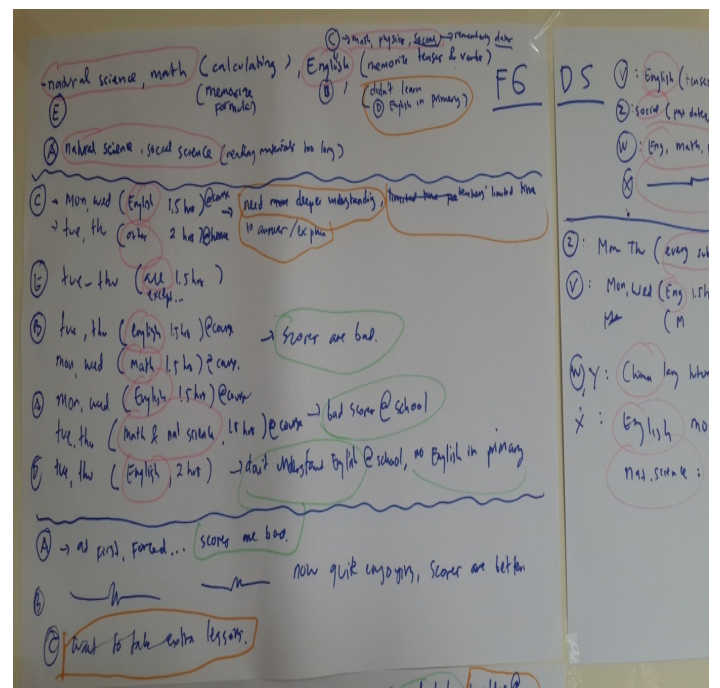


After the process of coding was done, the codes were grouped under the same categories to generate the themes. Themes collected were compared to confirm and validate the findings, as shown in the figure below:

Figure 2. Theme-generating process (codes emerged from coding process were carefully group into themes)

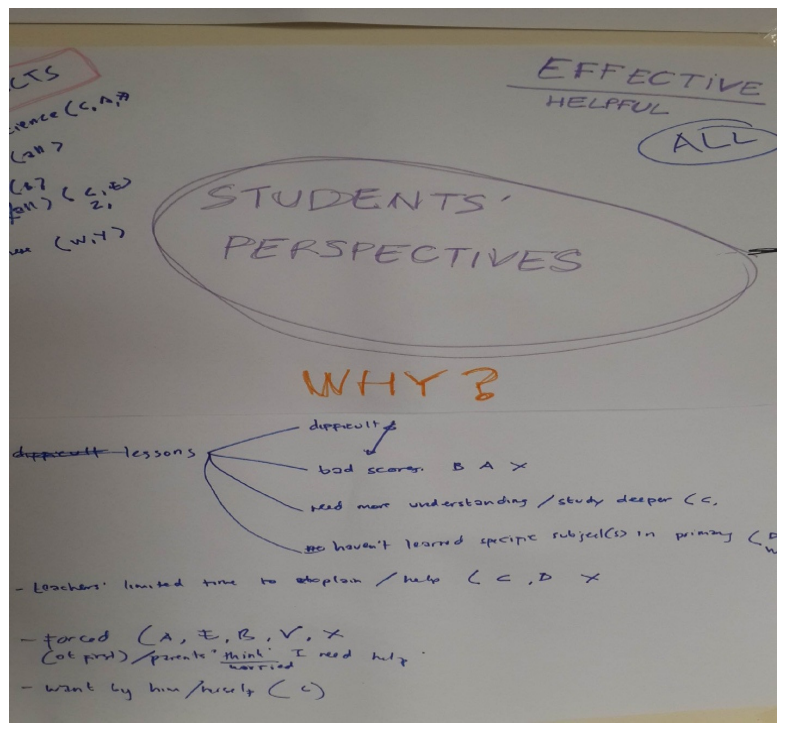

\section{Findings}

There were three themes emerged from the discussions related to students' perspectives on why they take extra tutoring service outside school hours: academic achievement and problem, parents' decision, and their own view on the usefulness of private tutoring.

\subsection{Theme 1: Academic achievement and problem}

Some students mentioned their difficulties in understanding certain subjects 'force' them to take extra tutoring session. They argued some subjects are very difficult to understand. Some excerpts related to these difficulties are:

Excerpt 1 (Focus group discussion 1) - E: In my opinion, math and natural science are the hardest, for me [...] I am not really good at calculating.

Excerpt 2 (Focus group discussion 1) - B: Math is hard for me, and sometimes English is hard too, especially when I have to memorize the tenses and verbs.

Excerpt 3 (Focus group discussion 2) - V: English is the hardest. I can't understand its tenses and grammar. $[\ldots]$ The next one is social science, $[\ldots]$

Excerpt 4 (Focus group discussion 2) - W: For me, Math is quite difficult, and English as well. Natural science, especially Physics, is hard [...]

Related to the students' difficulties in learning certain subjects, students also feel their scores in certain subjects are bad, especially the subjects they feel are difficult to understand.

Excerpt 5 (Focus group discussion 1) - A: I have English tutoring on Monday and Wednesday, same class with C, and Math and Natural science tutoring class on Tuesday and Thursday. I take these extra classes because I think my scores at school are not good so I think I need help in studying these subjects, and to increase my scores.

Excerpt 6 (Focus group discussion 2) - X: I have English tutoring on Monday and Wednesday, same place with $\mathrm{V}, \mathrm{W}$, and $\mathrm{Y}$ but different class because my level is different, and I have natural science tutoring on $\mathrm{mmm} . .$. Tuesday and Thursday [...] so, my reason, because I think I am not good at those subjects, and my parents were 
Sandy, W.

really worried when they first looked at my scores.

Students who did not get the lessons or subjects during their elementary years also argue private tutoring helps them to catch up so they will not be left behind too far from their colleagues who have already learned the lessons or subjects from their elementary years.

Excerpt 7 (Focus group discussion 1) - D: English is hard. I didn't study English during my primary years. I have English tutoring class on Tuesday and Thursday in the afternoon, from 4 to $6 \mathrm{pm}$. I think I don't understand English lesson at school, at all so my mother enrolled me to this tutoring class to help me catch up.

Excerpt 8 (Focus group discussion 2) - W: I and my brother have never learned Chinese during our elementary years and we knew nothing so our father enrolled us to Chinese language tutoring class on Tuesday and Thursday.

In contrary, there was student who has adequate understanding on her school lessons but decided to take extra tutoring service to deepen her knowledge. Teachers' limited time to help them in understanding the lessons is also their reason to take extra tutoring services.

Excerpt 9 (Focus group discussion 1) - C: [...] So I take tutoring because I think although I can understand most of the explanation and lessons from my teachers, I think I need more, and sometimes my teachers have limited time to answer questions [...]

Excerpt 10 (Focus group discussion 1) - D: [...] because my English scores were really bad, so I have to seek for help. My teacher at school is smart and very kind, but his time to help me is limited, we have 35 students in one class so I think it's hard for him to help me.

There are also students who invited tutors to teach almost every subject, regardless the difficulties they encounter, to help them in doing projects or homework.

Excerpt 11 (Focus group discussion 1) - E: My parents invite one personal tutor to my home and I learn almost every subject with him, Math, Natural science, English. He is I think one of the smartest men in this world... [Laughing]... I do my tutoring session from Tuesday to Thursday, 1.5 hours each.

Excerpt 12 (Focus group discussion 2) - Z: My parents invited personal tutor to teach me at home, and he teaches me almost every subjects, depends on what I need to finish my homework or assignments. [...] So, like... for example, I have English homework or assignment on Monday, so later my tutor will help me in explaining the best way to do that, and if I don't understand, he will explain. If I don't have any homework or assignment, he will teach me something for tomorrow's lessons.

From the excerpts shown above, Academic achievements and/or problems appear to be the main reason for students to take tutoring. Difficulties in learning appear to be the main reason to take extra tutoring service. In addition, teachers' limited time to give equal attention to all students also appears as one reason why students take tutoring. Although tutoring is also considered as a good way to deepen understanding and knowledge, difficulties in learning 'force' for the students to buy private tutoring services.

\subsection{Theme 2: Parents'decision}

Parents play crucial role in deciding whether to give their children extra tutoring service or not. They are often the ultimate decision maker to allow or force their children to take tutoring service, and they are the ones who pay tutoring fees for their children. In many cases, parents force their children to take extra tutoring services, mainly because their children have bad scores in certain subjects.

Excerpt 13 (Focus group discussion 1) - A: At first I didn't want to take it, but my mom forced me because my scores were bad. B: Yeah, the same with me. My mom forced me to take the classes. I couldn't reject because 
my scores were bad.

Excerpt 14 (Focus group discussion 2) - X: So, my reason, because I think I am not good at those subjects and my parents were really worried when they first looked at my scores, so they quite forced me to take extra tutoring classes.

Some of these children' parents did not force their children to take extra tutoring service, but because they requested to take extra tutoring lesson(s) and the parents thought that these services would be beneficial for their children so they bought the services for them.

Excerpt 15 (Focus group discussion 1) - C: I think because I need to take extra lessons to give me better understanding $[\ldots]$

Excerpt 16 (Focus group discussion 1) - E: I think I need it and my parents realized I need help in studying so they gave me this service.

From the excerpts, there are two types of parents who buy their children tutoring services: Parents who 'forced' their children to take private tutoring because their academic achievements are bad, and parents who did not push their children to take tutoring service but they granted their children's request to take private tutoring.

\subsection{Theme 3: Usefulness of private tutoring}

All participants agree the tutoring services they have taken help them to overcome their difficulties in learning, get better scores, deeper understanding, or to catch up.

Excerpt 17 (Focus group discussion 1) - A: So, mmm... I think tutoring is really helpful for me to understand difficult materials. C: Yes, I agree, and if I want to know the materials deeper, because sometimes our teachers at school only have limited time to explain certain materials. D: Mmm... For me, tutoring really helps, because I never learned English before and now I know English a little bit better [...]

Excerpt 18 (Focus group discussion 2) - X: Okay... mmm... in my opinion, the tutoring classes I take are quite helpful [...] I think I can get more explanation in my tutoring rather than at school.

Excerpt 19 (Focus group discussion 2) - Z: I think tutoring is very helpful. [...] Since I took tutoring, my scores are getting better.

Students think private tutoring they bought is useful to help them to raise their scores, deepen their understanding, or to catch up. This theme also indicates how students trust tutoring services to help them.

To conclude, the themes emerged from the two focus group discussions were similar, albeit with little differences in wording. Academic achievements and/or problems, parents' decision, and the usefulness of private tutoring services are the main themes yielded from the two focus group discussions.

\section{Findings Analysis}

Participants of this study revealed several factors related to their academic achievement and problem that 'forced' them to take extra tutoring service. First, they found some subjects are hard to master or to understand. The subjects are varied depend on students' personal experience and reasons, but most of them agree the difficulties in learning certain subjects or lessons lead to bad achievements or scores. Noticeably, subjects like Natural Science, Math, and English were often mentioned by the participants and the findings also reveal the participants take extra tutoring services on these subjects. Second, students also take private tutoring on subjects they never learned before during their primary years and think private tutoring helps them to catch up on those subjects. These facts show that difficulties in learning certain subjects cause bad achievements and scores, and extra tutoring is considered effective to help them to understand the subjects and raise their scores. This finding 
Sandy, W.

is similar to Suraweera's (2011) finding which revealed half participants had difficulty in understanding the subjects and decided to take extra tutoring to understand the lessons. Although on the other part of the findings show there is a student who takes private tutoring to deepen her knowledge or students who invited personal tutors to come to teach almost every subjects and help them in doing homework or assignments, the main function of private tutoring services as the source of assistance to comprehend the subjects or to expand and deepen understanding in certain subjects or topics (Baker, 2012; Bray, 2012; Silova, 2012) sounds true based on the findings.

As mentioned before, subjects like Natural Science, Math, and English were the ones 'favored' by the participants to get extra tutoring on. Interestingly, those subjects are also the main subjects in the national examination for secondary students. There are participants, who mentioned subjects which are not related to national examinations like Social Science and Chinese language, but interestingly the student who mentioned social science does not take private tutoring on that subject and the students who mentioned Chinese language take tutoring service to catch up because they never learned that subject before. All subjects have their own examinations and although no participant mentioned directly about national examinations during the discussions, looking at the subjects they chose to get extra tutoring on may indicate the importance of these subjects for them.

Related to difficulties in learning certain subjects, participants also argued teachers' limited time to give attention to all students in classroom is one of the reasons they take extra tutoring services. In this school, one classroom consists of 35-40 students. This amount poses problem because teacher cannot give full and equal attention to all class members. Furthermore, they cannot interact in a more engaging and personal sessions with their teachers, especially if they do not understand specific lessons and personally want to get further explanation. This problem does not occur in tutoring due to smaller class size and even some students have personal tutor comes to teach them at home and give full attention. Similar to this finding, Bray and Lykins (2012, p. 27-28) also consider class size as an issue which they argue "small classes may allow teachers to engage in more interactive pedagogy, giving students more opportunity to ask questions and gain clarifications". This finding should be seriously considered by the school or the policy makers to further think about the ideal amount of students in a classroom so the teachers can give equal amount of attention to all the students.

In this research, there were two arguments emerged from the students related to their parents' decision on giving them private tutoring: They were forced to take private tutoring, and they requested it. Some participants admitted they were forced to take private tutoring because their scores were bad on certain subjects, and their parents were afraid if they fail. This argument is congruent to several findings underpinning parents' anxiety about their children's achievement (Bray, 2013; Ireson \& Rushforth, 2005) and their fear to be labeled as 'fail' parents (Bray, 2013). The second argument, which is not found in previous literature, is there were students who requested their parents to buy them private tutoring service. This is quite surprising because at the very young age, they already acknowledge 'the importance' of private tutoring for them and their study, although their intentions in taking private tutoring were still closely related to the previous theme (bad scores, deepen understanding) and the final decision was ultimately made by their parents. This further show that parents also play important role in boosting the demands of private tutoring services, just like what Heyneman (2011) reported that parents choose shadow education to help the students in their academic problems because the parents have a natural tendency to support their children with their education in any way possible and view private tutoring is reliable to help their children.

All of the participants agree private tutoring is an effective way to help them based on what they need: to help them understand difficult materials, to catch up or raise their scores, to get more explanation, and to deepen their understanding on certain lessons. The participants confidently said their extra tutoring services are really helpful to achieve what they want and need from tutoring. This theme supports previous studies which argue private tutoring is helpful for the students (Bray \& Lykins, 2012; Brehm \& Silova, 2014; Safarzynska, 2013; Toh, 2008). Although some of them were forced to take private tutoring by their parents due to reasons like low achievements and learning difficulties, but later they expressed their enjoyment because their tutoring sessions 
significantly affect their achievement in schooling and do not see tutoring as a burden for them.

\section{Conclusion}

This study revealed students' perspectives on why they are willing to spend their time and money to buy private tutoring services. Three main themes appeared:

$>\quad$ Academic achievements and/or problem. First, difficulties in learning and understanding certain subjects, which lead to bad achievements and scores 'force' the students to take private tutoring and private tutoring is considered as the best way to help them. Another finding is students take private tutoring service to maintain their achievement and deepen their understanding in certain subjects. Second, teachers' limited time in classroom due to big number of students in classroom causes teacher cannot give full and equal attention to all students and private tutoring is considered as the answer for this problem due to smaller class size and even some students have personal tutor comes to teach at home and give full attention personally.

$>\quad$ Parents' decision. Two arguments related to parents' decision appear in this study. First, they were forced to take private tutoring due to parents' anxiety because their achievements and scores were bad. Second, they consciously requested their parents to buy private tutoring for them to help them raise and/or maintain their achievements.

$>\quad$ Usefulness of private tutoring. All participants in this study agree private tutoring has significant impact and delivers what they need from it: to help them understand difficult subjects, to catch up or raise and maintain their scores, to get more explanation, and to deepen their understanding on certain subjects.

\subsection{Implications}

Schools and policymakers may pay close attention to this research's result. Students in this study revealed that teachers' limited time to give equal attention to all students due to big classroom size 'forces' them to buy extra tutoring outside school hours, and prefer private tutoring rather than school teachers to help them in overcoming academic problems. These phenomena should be viewed as an early warning for teachers, schools, and policymakers because their tutors have slowly earned more 'trust' than school teachers to help students in overcoming academic problems (Bray, 2007). These phenomena have to be taken into serious consideration and schools and policymakers may start to do extensive study to produce reliable policies to improve students' experience in schooling and tackle the issue of teachers' limited time or classroom size to improve the quality of education service in general.

The 'trust' from students to tutoring services also shows the effect of privatization in education, where students encourage their choice and consider private services provide a more reliable help (Lubienski, 2008) and become a necessity to gain education success. This fact may exacerbate inequality because only those who can afford private tutoring services have bigger chance to succeed in schooling (Brehm \& Silova, 2014). Policymakers should consider this fact seriously and realize that the privatization is unavoidable in this modern era, and they should start considering policies to tackle the possibility of inequality and at the same time improve their quality and reliability in education service or else they will be left behind as the 'consumers' prefer private services over them (Aurini \& Davies, 2003).

As the 'consumers', students have their reasons on why they buy private tutoring services. These reasons play crucial role in shaping the market of private tutoring and act as the driving force of the growth of this rapidly-expanding shadow education market. The practitioners or providers of tutoring services may see this study as an encouragement that students are starting to trust the impact of such services, but they have to improve the services because they now have to bear more responsibilities in tutoring the students to ensure that 
Sandy, W.

the services they offer can answer the demands and needs of the students.

\subsection{Limitations and Suggestions}

This research is subjected to several limitations. First, this study only covers small scope of sample (10 students) from the same school. Therefore, the results of this study could not represent the whole students that buy private tutoring services in the whole Indonesia. Second, there are several interesting and researchable topics related to shadow education which are not covered in this study, particularly factors related to students' perspectives on buying private tutoring services, such as: socioeconomic factors, and the consideration to choose particular tutors or tutoring franchises. Third, this study does not analyze parents' perspectives on buying private tutoring services to their children and this perspective may further open up interesting findings since this study found out they are the ones who decided whether their children should take private tutoring or not and pay for the services. These limitations should not downgrade this study in general but those may be seen as a possibility to conduct research around those factors in the future. Conducting research based on the topics above may bring other new perspectives to the literature of shadow education and open up possibilities in analyzing shadow education from wider perspectives.

Acknowledgement: The writer would like to express his sincere gratitude to Immanuel Junior High School Pontianak, where the data collection process was held and the principal of the school who gave permission to contact the participants and their parents and even prepared classroom for the focus group discussions. The writer also would like to thank all participants who were willing to spare their time to attend the focus group discussion during their sports meeting time. The writer also would like to thank the parents of the participants who gave consent to the participants to take part in this study.

\section{References}

Aurini, J. (2006). Crafting legitimation projects: An institutional analysis of private education businesses. Sociological Forum, 21(1), 83-111. https://doi.org/10.1007/s11206-006-9004-8

Aurini, J., \& Davies, S. (2003). The transformation of private tutoring: Education in franchise form. Halifax: The Annual Meetings of the CSAA.

Baker, D. P. (2012). Private tutoring. PERIGlobal. Retrieved from https://www.youtube.com/watch?v=Ius9fpCtpQw\&list=UUYltfiG-G7ZrhBeIfw2Cyog\&index $=5$

Baker, D. P., \& LeTendre, G. K. (2005). National differences, global similarities: World culture and the future of schooling. Stanford University Press.

Baker, D. P., Akiba, M., LeTendre, G.K., \& Wiseman, A. W. (2001). Worldwide shadow education: Outsideschool learning, institutional quality of schooling, and cross-national mathematics achievement. Educational Evaluation and Policy Analysis, 23(1), 1-17. https://doi.org/10.3102/01623737023001001

Ball, S. J. (2007). Education plc. London: Routledge.

Bento, A. V., \& Ribeiro, M. I. (2013). The phenomenon of private tutoring: implications for public education. Global Education Review, 1(5), 70-74.

Berg, B. L. (2001). Qualitative Research Methods for the Social Sciences. London: Allyn and Bacon.

Boyatzis, R. E. (1998). Transforming qualitative information: Thematic analysis and code development.

Thousand Oaks, CA: SAGE.

Braun, V., \& Clarke, V. (2008). Using thematic analysis in psychology. Qualitative research in psychology, 3(2), 77-101. https://doi.org/10.1191/1478088706qp063oa

Bray, M. (2007). The shadow education system: private tutoring and its implications for planners. Paris: UNESCO International Institute for Educational Planning (IIEP).

Bray, M. (2011). The challenge of shadow education: Private tutoring and its implications for policy makers in the European Union. Education European Commission. 
Bray, M. (2012). Private tutoring. PERIGlobal. Retrieved from https://www.youtube.com/watch?v=ds_ceOQm7KI\&list=UUYltfiG-G7ZrhBeIfw2Cyog

Bray, M., \& Kwo, O. (2013). Behind the façade of fee-free education: Shadow education and its implications for social justice. Oxford Review of Education, 39(4), 480-497. https://doi.org/10.1080/03054985.2013.821852

Bray, M., \& Lykins, C. (2012). Shadow education: Private supplementary tutoring and its implications for policy makers in Asia. Mandaluyong City, Philippines: Asian Development Bank.

Bray, M., \& Silova, I. (2006). The private tutoring phenomenon: International patterns and perspectives. In I. Silova, V. Budiene, \& M. Bray (Eds.), Education in a hidden marketplace: Monitoring of private tutoring (pp. 27-42). New York, NY: Open Society Institute.

Brehm, W. C., \& Silova, I. (2014). Hidden privatization of public education in Cambodia: Equity implications of private tutoring. Journal for Educational Research Online, 6(1), 94-116.

Buchmann, C., Condron, D. J., \& Roscigno, V. J. (2010). Shadow education: Theory, analysis and future directions: a rejoinder. Social forces, 89(2), 483-490.

Budiene, V., \& Zabulionis, A. (2006). Lithuania. In I. Silova, V. Budiene, \& M. Bray (Eds.), Education in a hidden marketplace: Monitoring of private tutoring (pp. 211-236). New York, NY: Open Society Institute.

Burch, P. (2009). Hidden markets: the new education privatization. New York, NY: Routledge.

Cohen, L., Manion, L., \& Morisson, K. (2000). Research methods in education. London: Routledge. https://doi.org/10.4324/9780203224342

Dang, H. A. (2008). Private tutoring in Vietnam: An investigation of its causes and impacts with policy implications. Saarbrücken: VDM Verlag Dr. Muller.

Das, G. C., \& Das, R. (2013). An empirical view on private tutoring in school mathematics of Kamrup district. International journal of scientific and research publications, 3(5), 1-8.

Dawson, W. (2010). Private schooling and mass schooling in East Asia: Reflections of inequality in Japan, South Korea, and Cambodia. Asia pacific education review, 11(1), 14-24. https://doi.org/10.1007/s12564-009-9058-4

Dierkes, J. (2008). Japanese shadow education: The consequences of school choice. In M. Forsey, S. Davies, \& G. Walford (Eds.), The globalization of school choice? (pp. 231-248). Oxford: Symposium Books,.

Foondun, A. R. (1998). Private tuition, a comparison of tutoring practices at the primary level in Mauritius and some Southeast Asian countries. Bangkok: UNICEF East Asia \& Pacific Regional Office.

Ganesha Operation. (2017).Tentang ganesha operation [In Indonesian]. Retrieved from http://www.ganesha-operation.com/about/\#!/history

Hamid, M. Sussex, O. R., \& Khan, A. (2009). Private tutoring in English for secondary school students in Bangladesh. TESOL quarterly, 43(2), 281-308. https://doi.org/10.1002/j.1545-7249.2009.tb00168.x

Heyneman, S. P. (2011). Private tutoring and social cohesion. Peabody Journal of Education, 86(2), 183-188. https://doi.org/10.1080/0161956X.2011.561662

Howitt, D., \& Cramer, D. (2000). First steps in research and statistics. London: Routledge.

Hrynevych, L., Toropova, A., Pylnyk, T., Sereda, L., \& Gerasevich, U. (2006). Ukraine. In In I. Silova, V. Budiene, \& M. Bray (Eds.), Education in a hidden marketplace: Monitoring of private tutoring (pp. 305-326). New York, NY: Open Society Institute.

Ireson, J., \& Rushforth, K. (2005). Mapping and evaluating shadow education. ESRC Research Project RES-000-23-0117, University of London.

Kim, H. J. (2004). Analysing the effects of the high school equalization policy and the college entrance system on private tutoring expenditure in Korea. KEDI Journal of Educational Policy, 1(1), 5-24.

Kim, J. H., \& Park, D. K. (2010). The determinants of demand for private tutoring in South Korea. Asia Pacific Education Review, 11(3), 411-421. https://doi.org/10.1007/s12564-009-9067-3

Kwok, P. (2001). Local knowledge and value transformation in East Asian mass tutorial schools. International Education Journal, 2(5), 86-97.

Lee, J. (2007). Two worlds of private tutoring: The prevalence and causes of after-school mathematics tutoring in 
Sandy, W.

Korea and the United States. Teachers College Record, 109(5), 1207-1234.

Lipman, P. (2004). High stakes education: Inequality, globalization, and school reform. New York: Routledge/Falmer. https://doi.org/10.4324/9780203465509

Lodico, M. G., Spaulding, D. T., \& Voegtle, K. H. (2006). Methods in educational research. San Francisco: Jossey-Bass.

Lubienski, C. (2008). Educational innovation and diversification in school choice plans. Education and the Public Interest Center, School of Education, University of Colorado.

Marczyk, G., DeMatteo, D., \& Festinger, D. (2005). Essentials of research design and methodology. New Jersey: John Wiley \& Sons, Inc.

Matiashvili, A., \& Kutateladze, N. (2006). Georgia. In I. Silova, V. Būdienė, \& M. Bray (Eds.), Education in a hidden marketplace: Monitoring of private tutoring (pp. 191-210). New York: Open Society Institute.

Mori, I., \& Baker, D. (2010). The origin of universal shadow education: What the supplementary education phenomenon tells us about the postmodern institution of education. Asia Pacific Education Review, 11(10), 36-48. https://doi.org/10.1007/s12564-009-9057-5

OECD. (2010). PISA 2009 Results: What students know and can do: student performance in reading, mathematics and science. Paris: Organisation for Economic Co-operation and Development (OECD). https://doi.org/10.1787/9789264091450-en

Oller, A. \& Glasman, D. (2013). Education as a market in France: Forms and stakes of private tutoring. In Bray, M., Mazawi, A.E., \& Sultana, R.G. (eds.). Private tutoring across the Mediterranean: Power dynamics and implications for learning and equity (pp. 77-91). Rotterdam: Sense Publishers. https://doi.org/10.1007/978-94-6209-237-2_5

Primagama. (2017). Primagama [In Indonesian]. Retrieved from http://primagamasiap.com/tentang-primagama

Reay, D., \& Wiliam, D. (1999). 'I'll be a nothing': Structure, agency and the construction of identity through assessment. British Educational Research Journal, 25(3), 343-354. https://doi.org/10.1080/0141192990250305

Safarzynska, K. (2013). Socio-economic determinants of demand for private tutoring. European Sociological Review, 29(2), 139-154. https://doi.org/10.1093/esr/jcr045

Saldana, J. (2009). The coding manual for qualitative researchers. Los Angeles, CA: SAGE.

Seth, M. J. (2002). Education fever: Society, politics, and the pursuit of schooling in South Korea. Honolulu: University of Hawai'i Press.

Sharma, Y. (1997). A lesson in exam pressure. South China morning post, 22 April, page 18.

Silova, I. (2012). Private tutoring. PERIGlobal. Retrieved from https://www.youtube.com/watch?v=t8Vx48KtnWI\&list=UUYltfiG-G7ZrhBeIfw2Cyog\&index=6

Silova, I., \& Kazimzade, E. (2006). Azerbaijan. In I. Silova, V. Budiene, \& M. Bray (Eds.), Education in a hidden marketplace: Monitoring of private tutoring (pp. 113-142). New York, NY: Open Society Institute.

Silova, I., Budiene, V., \& Bray, M. (Eds.). (2006). Education in a hidden marketplace: Monitoring of private tutoring. New York, NY: Open Society Institute.

Southgate, D. E. (2009). Determinants of shadow education: a cross-national analysis (Ph. D. dissertation). Ohio State University, $\mathrm{OH}$.

Stevenson, D. L., \& Baker, D. P. (1992). Shadow education and allocation in formal schooling: Transition to university in Japan. American journal of sociology, 97(6), 1639-1657. https://doi.org/10.1086/229942

Suraweera, A.V. (2011). Dr. Kannangara's free education proposals in relation to the subsequent expansion of the tuition industry. Dr. C.W.W. Kannangara Memorial Lecture 22, Mahargama, Sri Lanka: Department of Research and Development, National Institute of Education.

Tan, J. (2009). Private tutoring in Singapore: bursting out of the shadows. Journal of Youth Studies, 12(1), 93-103.

Tansel, A., \& Bircan, F. (2005). Effect of private tutoring on university entrance examination performance in Turkey. Economic Research Center, Middle East Technical University.

Toh, M. (2008). Tuition nation. Asiaone News. Retrieved from 
http://www.asiaone.com/News/Education/Story/A1Story2008061671121.html

Wittwer, J (2014). Discussion: Conditions, processes, and effects of private tutoring. Journal for Educational Research Online, 6(1), 124-138.

Zhang, W., \& Bray, M. (2013). Researching supplementary education: Plans, realities, and lessons from fieldwork in China. International perspectives on education and society, 22(1), 67-94.

https://doi.org/10.1108/S1479-3679(2013)0000022002 
Sandy, W. 